\title{
Early candidate biomarkers found from urine of astrocytoma rat before changes in MRI
}

\author{
Yanying $\mathrm{Ni}^{1}$, Fanshuang Zhang ${ }^{1}$, Manxia $\mathrm{An}^{1}$, Wei $\mathrm{Yin}^{1}$ and Youhe Gao ${ }^{1,2^{*}}$ \\ ${ }_{1}$ Department of Pathophysiology, Institute of Basic Medical Sciences, Chinese Academy of Medical \\ Sciences, School of Basic Medicine, Peking Union Medical College, Beijing, China \\ ${ }_{2}$ Department of Biochemistry and Molecular Biology, Beijing Normal University, Gene Engineering \\ and Biotechnology Beijing Key Laboratory, Beijing, China \\ *Corresponding author: Youhe Gao, Department of Biochemistry and Molecular Biology, Beijing \\ Normal University, Gene Engineering and Biotechnology Beijing Key Laboratory, Beijing, 100875, \\ PR. of China, Tel: 86-10- 58804382; E-mail: gaoyouhe@bnu.edu.cn
}

\begin{abstract}
Astrocytoma is the most common aggressive glioma and its early diagnosis remains difficult. Biomarkers are changes associated with the disease. Urine, which is not regulated by homeostatic mechanisms, accumulates changes and therefore is a better source for biomarker discovery. In this study, C6 cells were injected into Wistar rats brain as astrocytoma model. Urine samples were collected at day 2, day 6, day 10 and day 13 after injection, and the urinary proteomes were analyzed. On the 10th day, lesions appeared in magnetic resonance imaging. On the 13th day, clinical symptoms started. But differential urinary proteins were changed with the development of the astrocytoma, and can provide clues even on the 2nd and 6th day. Twenty-seven differential proteins with human orthologs had been reported to associate with astrocytoma. Thirty-nine proteins were verified in four more rats as candidate biomarkers of astrocytoma using multiple-reaction monitoring. A panel of differential urinary proteins may provide early biomarkers for diagnose of astrocytoma.
\end{abstract}

Keywords: Urine proteome, Animal model, Biomarker, Astrocytoma

\section{Introduction}

Gliomas are the most frequent primary tumors of the central nervous system, accounting for more than $60 \%$ of all brain tumors [1]. Among them, glioblastoma (GBM) is the most common aggressive glioma, and the average survival rate remains low [2]. The standard combination of surgery and radiotherapy or chemotherapy can only extend the progression-free survival time for 12-18 months, with a high risk of recurrence [3]. In addition, the incidence of astrocytoma has increased annually by $1-2 \%$ in the past years [4]. Therefore, a precise early diagnosis of astrocytoma is crucial for the early determination of appropriate therapeutic strategies. 
Changes associated with physiological or pathophysiological processes are the most fundamental characteristic of biomarkers [5]. Urine which is not regulated by homeostatic mechanisms, has the potential to accumulate changes and serve as a better source for disease biomarker discovery [6]. However, urine can be affected by various factors, such as age, diet, and drugs $[7,8]$. To minimize these confounding factors, animal models were used to mimic the pathophysiological changes of diseases to search for valuable clues, instead of clinical samples [9].

The rapidly proliferating rat $\mathrm{C6}$ cell line is morphologically similar to GBM when injected into the brain of neonatal rats [10]. The C6 model is closer to the usual histological characteristics of spontaneous GBM when using Wistar rats rather than other strains, including nuclear pleomorphism, high mitotic index, hemorrhage, necrosis and parenchymal invasion [11]. In this study, urine samples were used to identify the candidate biomarkers involved in GBM diagnosis, and further monitor prognosis. The urinary proteome at 2 days, 6 days, 10 days and 13 days was analyzed. This study will not only benefit patients with GBM but also give us a more comprehensive understanding of the clinical significance of urine (Fig.1).

\section{Methods}

\section{Ethics statement}

All protocols involving animals were approved by the Institute of Basic Medical Sciences Animal Ethics Committee, Peking Union Medical College. Male Wistar rats weighing 200 to $230 \mathrm{~g}$ were obtained from the Institute of Laboratory Animal Science, Chinese Academy of Medical Science \& Peking Union Medical College. All animals were housed with free access to water and a standard laboratory diet under controlled room temperature $\left(22 \pm 1^{\circ} \mathrm{C}\right)$ and humidity conditions $(65-70 \%)$. All efforts were made to minimize suffering.

\section{Cell culture.}

Rat C6 cells were obtained from the Chinese Academy of Medical Science \& Peking Union Medical College (Beijing, China) and cultured at $37^{\circ} \mathrm{C}$ in DMEM, supplemented with $10 \%$ fetal bovine serum, $100 \mathrm{IU} / \mathrm{mL}$ penicillin and $100 \mu \mathrm{g} / \mathrm{mL}$ streptomycin in a humidified atmosphere of 5\% CO2 air (Thermo Fisher Scientific, Inc., Waltham, MA, USA) [12]. Cells in the logarithmic growth phase were used for the experiment.

\section{Rat C6 astrocytoma model.}

Male Wistar rats were randomly divided into two groups (20 rats in each group). The astrocytoma model was established as described previously [13]. Briefly, under 
general anesthesia with $2 \%$ pelltobarbitalum natricum $(40 \mathrm{mg} / \mathrm{kg}$ body weight), the skull was drilled at $1 \mathrm{~mm}$ anterior to the anterior fontanelle and $3 \mathrm{~mm}$ right of the midline, and $10 \mu \mathrm{l}$ of cell suspension containing 106 cells was injected using a microsyringe (SHANGHAI HIGH PIGEON INDUSTRY TRADE \& Co., LTD CHINA). Rats in the control group were administrated PBS only. The rats' weights were monitored twice a day. Rats with similar clinical symptom were chosen for further analysis, which will help to find biomarkers in the same period of GBM.

\section{Magnetic resonance imaging analysis}

MRI was performed using a 7 T MRI animal system (Agilent, US) on days 6, 10 and 13 after tumor cell implantation. Rats were monitored under anesthesia. The parameters were set as follows: $\mathrm{T} 1(\mathrm{TR} / \mathrm{TE}=500 / 15.69 \mathrm{~ms}, 16$ slices with FOV $40 \times 40 \mathrm{~mm}^{2}$, matrix $\left.=256 \times 256\right)$. Acquisition duration was $3 \mathrm{~min}$ and $44 \mathrm{~s}$; T2-weighted sequence $(\mathrm{TR} / \mathrm{TE}=3500 \mathrm{~ms} / 72.00 \mathrm{~ms}$, with repetition time $1,000 \mathrm{~ms}$, matrix $=256 \times 256)[14]$.

\section{Brain histopathology}

Rats were sacrificed using overdose anesthesia and perfused with $4 \%$ paraformaldehyde via the left ventricle. After perfusion with $0.9 \%$ saline and ice-cold $4 \%$ paraformaldehyde, the brains were removed and post-fixed in $4 \%$ paraformaldehyde in PBS overnight, and then the tissues were embedded in paraffin, sliced at 2-3 $\mu \mathrm{m}$, and stained with hematoxylin and eosin (H\&E) [15].

\section{Urinary protein sample preparation and LC-MS/MS analysis}

Proteins were extracted as follows [16]: (1) centrifugation at $2000 \times \mathrm{g}$ and $12000 \times \mathrm{g}$ for 30 minutes at $4{ }^{\circ} \mathrm{C}$, respectively; (2) precipitation by ethanol overnight at $4{ }^{\circ} \mathrm{C}$; (3) dissolution by lysis buffer ( $8 \mathrm{M}$ urea, $2 \mathrm{M}$ thiourea, $25 \mathrm{mM}$ dithiothreitol and $50 \mathrm{mM}$ Tris).

For each urine sample, some proteins were separated using sodium dodecyl sulfate polyacrylamide gel electrophoresis (SDS-PAGE), while some proteins were digested by trypsin (Trypsin Gold, Mass Spec Grade, Promega, Fitchburg, WI, USA) in 10-kD filter units (Pall, Port Washington, NY, USA) [17]. UA (8 M urea in $0.1 \mathrm{M}$ Tris- $\mathrm{HCl}$, $\mathrm{pH} 8.5$ ) was added to wash the proteins at $14000 \times \mathrm{g}$ for $20 \mathrm{~min}$ at $18^{\circ} \mathrm{C}$. $\mathrm{NH} 4 \mathrm{HCO} 3$ was added subsequently to wash the protein. Then, the urinary proteins were denatured by dithiothreitol and alkylated by iodoacetamide. The proteins were digested with trypsin at $37^{\circ} \mathrm{C}$ for 14 hours. The collected peptide mixtures were desalted using Oasis HLB cartridges (Waters, Milford, MA) and then dried by vacuum evaporation (Thermo Fisher Scientific, Bremen, Germany). 
The digested peptides were acidified with $0.1 \%$ formic acid, then loaded onto a reversed-phase micro-capillary column using a Waters UPLC system. The MS data were acquired using Thermo Orbitrap Fusion Lumos (Thermo Fisher Scientific, Bremen, Germany). Animals $(n=3)$ with the same clinical manifestations were randomly chosen from the astrocytoma group. Each sample was analyzed three times.

\section{Protein identification and label-free quantitation}

The MS/MS data were analyzed using Progenesis and Masccot (version 2.4.1, Matrix Science, London, UK). The parameters were set as follows: Swiss-Prot rat database (551,193 sequences; 196,822,649 residues); the fragment tolerance was $0.05 \mathrm{Da}$; the parent ion tolerance was $0.05 \mathrm{Da}$; the precursor mass tolerance was $10 \mathrm{ppm}$; two missed trypsin cleavage sites were allowed; and peptide identifications containing at least 2 identified peptides were accepted, as in a previous study [18]. Carbamidomethylation of cysteines was set as a fixed modification, and oxidation of methionine and protein N-terminal acetylation were set as variable modifications. After normalization, the fold change of abundance was used to analyze differential proteins between the control group and the astrocytoma group [19, 20].

\section{Multiple-Reaction Monitoring analysis}

Some differential proteins were validation using multiple-reaction monitoring (MRM). For targeted proteomic analysis, the dat file of GBM urine generated by conventional LC/MS/MS were imported into Skyline version 1.1. software. Skyline was employed to select the most intense peptide transitions, up to four or five transitions per peptide were selected and were traced on a QTRAP 6500 mass spectrometer (AB Sciex, Massachusetts, USA). All MS data were imported into Skyline, which was used for further peptide transitions selection and abundance calculations.

\section{Gene Ontology and Ingenuity Pathway Analysis}

All differentially expressed proteins identified between the control and astrocytoma groups were assigned a gene symbol using the Panther database (http://www.pantherdb.org/) and analyzed by Gene Ontology (GO) based on the molecular function, biological processes, and cellular component categories. For biological processes, all differentially expressed proteins were also analyzed by the IPA software (Ingenuity Systems, Mountain View, CA, USA) for pathway analysis, and network analysis.

\section{Statistical analysis}

Clinical symptoms, proteome analysis and MRM data were analyzed using the SPSS16.0 software package for statistical analysis. Comparisons between independent 
groups were conducted using one-way ANOVA followed by post hoc analysis with the least significant difference (LSD) test or Dunnett' s T3 test. P-values of less than 0.05 were considered different.

\section{Results and Discussion}

\section{Clinical symptoms}

After injection with C6 cells, there was no difference in clinical manifestations. However, on the 13th day, some GBM rats showed twitching, tachypnea, drowsiness and low symptom scores. The rats in the control group did not show any symptoms (Fig. 2A). All rats gained weight steadily after tumor cell implantation. Compared with control rats, the GBM rats' weights were significantly lower on the 13th day, and the weight was 1.04-fold higher in the control group than in the GBM group (Fig. 2B).

\section{MRI analysis}

Images of rat brains on the 6th day, 10th day and 13th day were obtained. For MRI imaging, the rats were in a supine position. Compared to the left brain, the right brain injected with tumor cells showed no obvious lesion on the 6th day after tumor cell implantation (Fig. 3A). On the 10th day, there was strong enhancement with an obscure boundary in the right brain on the T2 images (Fig. 3B). On the 13th day, the strong enhancement lesions were largger, and the midline shifted on the T2 images, showing an obvious effect of an intracranial placeholder, such as a midline shift (Fig. $3 C)$.

\section{Histopathology}

Rats were sacrificed and the brain tissue separated. H\&E staining is shown. Compared to normal tissues, there is tumor tissue in the right caudate nucleus on the 13th day (Fig. 4A). The tumor tissue in GBM rats exhibited invasive growth with an ill-defined margin (Fig. 4B). Nuclear condensation, fragmentation and pathologic mitosis are observed in the tumor tissue (Fig. 4C).

\section{Differential urinary proteins}

The urinary proteins were analyzed using Thermo Orbitrap Fusion Lumos. The urinary samples of three rats were analyzed three times to provide technical replicates (Table S1). In total, 778 proteins were identified (Table S2), and 124 differential proteins were selected according to the following criteria: 1) proteins with at least two unique peptides were allowed, 2) fold change $\geq 2$; and 3) $\mathrm{p}$ value $<0.05$. All differential proteins were significantly changed in the three rats' urine. 
Among the differential proteins, 109 have corresponding human orthologs, out of which 78 were down-regulated more than 2 -fold and 31 were up-regulated more than 2-fold (Table 1). Overall, 56 significantly changed proteins were selected in the 2nd day group (D2), 65 proteins in the D6 group, 61 proteins in the D10 group and 27 proteins in the D13 group, respectively. Among them, sixty-five differential proteins were repeatedly identified in different groups (Fig. S1).

On the 2nd and 6th day, GBM rats showed 90 differential urinary proteins with human orthologs. Among all differential proteins, 27 proteins that had been identified in the CSF, blood or brain tissue were reported to be associated with GBM (Table 2).

\section{MRM analysis}

Thirty-nine differential proteins, which were changed in all three rats, were selected for further validation in four additional individual urine samples using MRM. To obtain more confidence, 4-5 transitions were used for each peptide (Table S3). For MRM analysis, the technical variation in the triplicate runs was first calculated and $92.58 \%$ of proteins with $\mathrm{CV}<0.3$ (Table S3), indicating that the technical variation of MRM analysis was ideal.

For the differential proteins, 29 were down-regulated more than 2-fold in the MRM validation results. Glutamyl aminopeptidase was down-regulated in D2, D6, D10 and D13 groups, beta-glucuronidase was also significantly decreased in D2, D6 and D10 groups, which were consistent with MS/MS results (Fig 5). And 9 differential proteins were up-regulated more than 2-fold. Neutrophil gelatinase-associated lipocalin (NGAL) showed a significant elevation in D2 group, beta-2-microglobulin was also significantly increased in D13 group, which confirms the results of our proteome analysis. However, the MRM result of some differential proteins, such as growth and differentiation factor-15 (GDF15) and stanniocalcin-1 which had been reported to be associated with GBM, did not showed significant difference between control and D2 group, which may be due to its lower relative abundance, which requires larger samples and deeper identification for validation.

\section{Gene ontology and Ingenuity Pathway Analysis analyses of differential proteins}

The differential proteins were analyzed by the PANTHER classification system. In the biological process category (Fig 6A), the percentages of multicellular organismal processes and metabolic processes were overrepresented, whereas the biological adhesion and response to stimulus were underrepresented in astrocytoma group compared with the whole genome data. In the molecular category (Fig 6B), the percentage of catalytic activity was much higher, while the percentages of receptor and signal transducer activity were much lower in the astrocytoma group in relation to 
the whole genome data. In the cellular component category (Fig 6C), the membrane was overrepresented in D6/D10 and D13 groups, whereas extracellular region proteins were underrepresented, indicating that the membrane proteins play a role in the pathologic process of astrocytoma.

Canonical signaling pathways were analyzed to better understand the biological features of glioma. Alpha-actinin-4 (ACTN4), which was involved in VEGF signaling, decreased in the urine of three rats, which is consistent with a previous study's finding that ACTN4 plays a role in the development and progression of glioma [21]. The glutathione synthetase, which is involved in glutathione biosynthesis, decreased in urine. VEGF signaling and glutathione biosynthesis were enriched in the D2, D6 and D10 groups, and these results were consistent with previous work [22, 23], indicating that our proteomic data may reflect the information of glioma. In the acute phase response signaling, acute-phase proteins, such as complement C3 and C-reactive protein, which may reflect the inflammation and activation of the innate immune system during the course of glioma [24, 25].

The network analysis showed that the cellular death and survival networks were mostly affected (Fig 6D). Osteopontin (SPP1), which is primarily involved in immune responses, tissue remodeling and biomineralization, is a core component of these networks. NGAL (LCN2), extracellular superoxide dismutase (SOD3) and Beta-2-microglobulin (B2M) were up-regulated in these networks. Complement C3 (C3), Glutathione S-transferase P (GSTP1), alkaline phosphatase (ALPL), lysosomal acid phosphatase (ACP2) and ezrin (EZR) were down-regulated in relation to the control group and have been reported to play roles in GBM [26-28].

\section{Discussion}

NGAL complex activity was elevated in brain tumors and somay serve as a molecular marker for brain tumors [29]. NGAL protein may also be involved in glioma drug resistance and clinical prognosis [30]. Ciliary neurotrophic factor receptor subunit alpha, which participates in the formation of tumor-initiating cells in gliomas, is a marker that correlates with histological grade [31]. Serum acute phase reactant proteins were correlated with GBM in relation to their prognosis. Haptoglobin, previously reported to be involved in infection, tumor growth and migration, was identified as a GBM-specific serum marker [32, 33]. Alpha 1-acid glycoprotein, another serum acute phase reactant protein, was also identified in the serum of patient's with GBM [34]. The lysosomal marker cathepsin D (CATD), which was identified on the 6th day, was frequently overexpressed in glioblastomas [35]. The above differential proteins identified during the early stage may help in providing clues for the early diagnosis of the disease. 
Some differential proteins were continuously identified in the D2, D6, D10 or D13 groups. Chloride intracellular channel protein 1 expression presented a correlation with glioma, as higher expression levels were observed in tumor tissues [36]. GSTP1 was reported to show higher expression levels in meningeal tumors and GBM [37]. And a significant decrease in aminopeptidase N (AMPN) occurred concomitantly with tumor growth in glioma tissue [38]. These differential proteins continuously identified in the D2, D6, D10 or D13 groups may help in monitoring the development of the disease.

Most of the differentially expressed proteins that had not been reported to be associated with GBM in other studies may also play an important role and serve as new markers during the progression of this disease. For example, secreted phosphoprotein 24 , a bone matrix protein that can suppress pancreatic cancer growth [39] and lung cancer [40], may also be potential urinary markers of GBM.

Several differential proteins may appear in many different brain diseases. For example, AMPN was increased in the urine of both GBM rats and obstructive nephropathy rat [41]; CATD was decreased in the urine of GBM rats but increased in the urine of bladder cancer rats [42], which suggests that these diseases may share similar pathological processes [43]. Thus, it may be difficult to provide an accurate diagnosis using a single biomarker; a panel or collection of urinary proteins may be faster and more sensitive [44]. In this study, one hundred and nine differential proteins with human orthologs could be evaluated together to reflect the progression of GBM.

Compared to the urinary biomarker panel of another cancer, ovarian carcinoma, the protein changes in this study were substantially different. Distinct differential proteins were present in GBM and ovarian carcinoma [45]. The expression profile of differentially expressed proteins in different cancers illustrates that specific pathological conditions have their own biomarker combinations, and different diseases can be differentiated using different biomarker combinations.

In summary, clinical manifestation may provide clues to astrocytoma on the 13th day after tumor cell implantation, while the enhancement lesion appeared in MRI on the 10th day. However, the urinary differential proteins of three rats were changed with the development of the disease and can provide valuable clues by the $2 \mathrm{nd}$ and 6 th day. Among all the differential proteins in the early stage, 18 proteins were reported to be associated with GBM, suggesting that a panel or collection of urinary differential proteins in urine is a better choice for the early diagnosis of brain diseases (Fig 7). In future studies, we hope this work will help to identify astrocytoma biomarkers with clinical utility and will help to understand the role of urine as a better source in biomarker discovery, especially in brain diseases. 


\section{Acknowledgements}

This work was supported by the National Key Research and Development Program of China (2016 YFC 1306300); the National Basic Research Program of China (2013CB530850); Beijing Natural Science Foundation (7173264, 7172076) and funds from Beijing Normal University (11100704, 10300-310421102).

1. Wang, J.Y., Bettegowda, C. (2015) Genetics and immunotherapy: using the genetic landscape of gliomas to inform management strategies. J Neurooncol 123: 373-83.

2. Chen, L., Li, X., Liu, L., Yu, B., Xue, Y. et al. (2015) Erastin sensitizes glioblastoma cells to temozolomide by restraining $\mathrm{xCT}$ and cystathionine-gamma-lyase function. Oncol Rep 33: 1465-74.

3. Li, J.H., Song, D.Y., Xu, Y.G., Huang, Z., Yue, W. (2008) In vitro study of haematoporphyrin monomethyl ether-mediated sonodynamic effects on C6 glioma cells. Neurol Sci 29: 229-35.

4. Louis, D.N., Ohgaki, H., Wiestler, O.D., Cavenee, W.K., Burger, P.C. et al. (2007) The 2007 WHO classification of tumours of the central nervous system. Acta Neuropathol 114: 97-109.

5. Gao, Y. (2014) Roadmap to the Urine Biomarker Era. MOJ Proteomics \& Bioinformatics 1: 00005.

6. Gao, Y. (2013) Urine-an untapped goldmine for biomarker discovery? Sci China Life Sci 56: 1145-6.

7. Mullen, W., Gonzalez, J., Siwy, J., Franke, J., Sattar, N. et al. (2011) A pilot study on the effect of short-term consumption of a polyphenol rich drink on biomarkers of coronary artery disease defined by urinary proteomics. J Agric Food Chem 59: 12850-7.

8. Wu, J., Gao, Y. (2015) Physiological conditions can be reflected in human urine proteome and metabolome. Expert Rev Proteomics 12: 623-36.

9. Kinross, J.M., Drymousis, P., Jimenez, B., Frilling, A. (2013) Metabonomic profiling: a novel approach in neuroendocrine neoplasias. Surgery 154: 1185-92; discussion 1192-3.

10. Auer, R.N., Del Maestro, R.F., Anderson, R. (1981) A simple and reproducible experimental in vivo glioma model. Can J Neurol Sci 8: 325-31.

11. San-Galli, F., Vrignaud, P., Robert, J., Coindre, J.M., Cohadon, F. (1989) Assessment of the experimental model of transplanted C6 glioblastoma in Wistar rats. J Neurooncol 7: 299-304.

12. Pinheiro, A.M., Costa, S.L., Freire, S.M., Almeida, M.A., Tardy, M. et al. (2006) Astroglial cells in primary culture: a valid model to study Neospora caninum infection in the CNS. Vet Immunol Immunopathol 113: 243-7.

13. Zelenkov, P., Baumgartner, R., Bise, K., Heide, M., Meier, R. et al. (2007) Acute morphological sequelae of photodynamic therapy with 5 -aminolevulinic acid in the C6 spheroid model. J Neurooncol 82: 49-60.

14. Ulmer, S., Reeh, M., Krause, J., Herdegen, T., Heldt-Feindt, J. et al. (2008) Dynamic contrast-enhanced susceptibility-weighted perfusion MRI (DSC-MRI) in a glioma model of the rat brain using a conventional receive-only surface coil with a inner diameter of $47 \mathrm{~mm}$ at a clinical 1.5 T scanner. J Neurosci Methods 172: 168-72.

15. Boretius, S., Escher, A., Dallenga, T., Wrzos, C., Tammer, R. et al. (2012) Assessment of lesion pathology in a new animal model of MS by multiparametric MRI and DTI. Neuroimage 59 : 2678-88. 
16. Sun, W., Li, F., Wu, S., Wang, X., Zheng, D. et al. (2005) Human urine proteome analysis by three separation approaches. Proteomics 5: 4994-5001.

17. Wisniewski, J.R., Zougman, A., Nagaraj, N., Mann, M. (2009) Universal sample preparation method for proteome analysis. Nat Methods 6: 359-62.

18. Yuan, Y., Zhang, F., Wu, J., Shao, C., Gao, Y. (2015) Urinary candidate biomarker discovery in a rat unilateral ureteral obstruction model. Sci Rep 5: 9314.

19. Schmidt, C., Gronborg, M., Deckert, J., Bessonov, S., Conrad, T. et al. (2014 ) Mass spectrometry-based relative quantification of proteins in precatalytic and catalytically active spliceosomes by metabolic labeling (SILAC), chemical labeling (iTRAQ), and label-free spectral count. Rna 20: 406-20.

20. Old, W.M., Meyer-Arendt, K., Aveline-Wolf, L., Pierce, K.G., Mendoza, A. et al. (2005) Comparison of label-free methods for quantifying human proteins by shotgun proteomics. Mol Cell Proteomics 4: 1487-502.

21. Quick, Q., Skalli, O.(2010)Alpha-actinin 1 and alpha-actinin 4: contrasting roles in the survival, motility, and RhoA signaling of astrocytoma cells. Exp Cell Res 316: 1137-47.

22. Ren, T., Lin, S., Wang, Z., Shang, A. (2016) Differential proteomics analysis of low- and high-grade of astrocytoma using iTRAQ quantification. Onco Targets Ther 9: 5883-5895.

23. Szeliga, M., Albrecht, J. (2016) Glutamine Metabolism in Gliomas. Adv Neurobiol 13: 259-273.

24. Nijaguna, M.B., Schroder, C., Patil, V., Shwetha, S.D., Hegde, A.S. et al. (2015) Definition of a serum marker panel for glioblastoma discrimination and identification of Interleukin 1beta in the microglial secretome as a novel mediator of endothelial cell survival induced by C-reactive protein. J Proteomics 128: 251-61.

25. Cheng, Y.X., Li, F., Lu, J.Y., Li, M., Du, P. et al. (2011) Growth of G422 glioma implanted in the mouse brain was affected by the immune ability of the host. Chin Med J (Engl) 124: 1994-8.

26. Iwadate, Y., Matsutani, T., Hirono, S., Shinozaki, N., Saeki, N. (2016) Transforming growth factor-beta and stem cell markers are highly expressed around necrotic areas in glioblastoma. J Neurooncol 129: $101-7$.

27. Tynninen, O., Carpen, O., Jaaskelainen, J., Paavonen, T., Paetau, A. (2004) Ezrin expression in tissue microarray of primary and recurrent gliomas. Neuropathol Appl Neurobiol 30: 472-7.

28. Kijewska, M., Kocyk, M., Kloss, M., Stepniak, K., Korwek, Z. et al. (2016) The embryonic type of SPP1 transcriptional regulation is re-activated in glioblastoma. Oncotarget

29. Liu, M.F., Hu, Y.Y., Jin, T., Xu, K., Wang, S.H. et al. ( 2015 ) Matrix Metalloproteinase-9/Neutrophil Gelatinase-Associated Lipocalin Complex Activity in Human Glioma Samples Predicts Tumor Presence and Clinical Prognosis. Dis Markers 2015: 138974.

30. Zheng, L.T., Lee, S., Yin, G.N., Mori, K., Suk, K. (2009) Down-regulation of lipocalin 2 contributes to chemoresistance in glioblastoma cells. J Neurochem 111: 1238-51.

31. Lu, J., Ksendzovsky, A., Yang, C., Mehta, G.U., Yong, R.L. et al. (2012) CNTF receptor subunit alpha as a marker for glioma tumor-initiating cells and tumor grade: laboratory investigation. J Neurosurg 117: 1022-31.

32. Kumar, D.M., Thota, B., Shinde, S.V., Prasanna, K.V., Hegde, A.S. et al. (2010) Proteomic identification of haptoglobin alpha2 as a glioblastoma serum biomarker: implications in cancer cell migration and tumor growth. J Proteome Res 9: 5557-67.

33. Gollapalli, K., Ray, S., Srivastava, R., Renu, D., Singh, P. et al. (2012) Investigation of serum 
proteome alterations in human glioblastoma multiforme. Proteomics 12: 2378-90.

34. Matsuura, H., Nakazawa, S. (1985) Prognostic significance of serum alpha 1-acid glycoprotein in patients with glioblastoma multiforme: a preliminary communication. J Neurol Neurosurg Psychiatry 48: $835-7$.

35. Giatromanolaki, A., Sivridis, E., Mitrakas, A., Kalamida, D., Zois, C.E. et al. (2014) Autophagy and lysosomal related protein expression patterns in human glioblastoma. Cancer Biol Ther 15: $1468-78$.

36. Setti, M., Osti, D., Richichi, C., Ortensi, B., Del Bene, M. et al. (2015) Extracellular vesicle-mediated transfer of CLIC1 protein is a novel mechanism for the regulation of glioblastoma growth. Oncotarget 6: 31413-27.

37. Stavrinou, P., Mavrogiorgou, M.C., Polyzoidis, K., Kreft-Kerekes, V., Timmer, M. et al. (2015) Expression Profile of Genes Related to Drug Metabolism in Human Brain Tumors. PLoS One 10: e0143285.

38. Ramirez-Exposito, M.J., Mayas-Torres, M.D., Carrera-Gonzalez, M.P., Jimenez-Pulido, S.B., Illan-Cabeza, N.A. et al. (2014) Silver(I)/6-hydroxyiminolumazine compounds differently modify renin-angiotensin system-regulating aminopeptidases $A$ and $N$ in human neuroblastoma and glioma cells. J Inorg Biochem 138: 56-63.

39. Li, C.S., Tian, H., Zou, M., Zhao, K.W., Li, Y. et al. ( 2015 ) Secreted phosphoprotein 24 kD (Spp24) inhibits growth of human pancreatic cancer cells caused by BMP-2. Biochem Biophys Res Commun 466: 167-72.

40. Lee, K.B., Murray, S.S., Duarte, M.E., Spitz, J.F., Johnson, J.S. et al. (2011) Effects of the bone morphogenetic protein binding protein spp24 (secreted phosphoprotein $24 \mathrm{kD}$ ) on the growth of human lung cancer cells. J Orthop Res 29: $1712-8$.

41. Schaffer, P., Molnar, L., Lukasz, P., Mattyus, I., Verebely, T. et al. (2002) [Urinary enzyme excretion in childhood uropathy]. Orv Hetil 143: 2135-9.

42. Osman, I., Bajorin, D.F., Sun, T.T., Zhong, H., Douglas, D. et al. (2006) Novel blood biomarkers of human urinary bladder cancer. Clin Cancer Res 12: 3374-80.

43. Shao, C., Li, M., Li, X., Wei, L., Zhu, L. et al. (2011)A tool for biomarker discovery in the urinary proteome: a manually curated human and animal urine protein biomarker database. Mol Cell Proteomics 10: M111.010975.

44. Zhao, M., Li, M., Li, X., Shao, C., Yin, J. et al. (2014) Dynamic changes of urinary proteins in a focal segmental glomerulosclerosis rat model. Proteome Sci 12: 42.

45. Abdullah-Soheimi, S.S., Lim, B.K., Hashim, O.H., Shuib, A.S. (2010) Patients with ovarian carcinoma excrete different altered levels of urine CD59, kininogen-1 and fragments of inter-alpha-trypsin inhibitor heavy chain $\mathrm{H} 4$ and albumin. Proteome Sci 8: 58.

46. Codo, P., Weller, M., Kaulich, K., Schraivogel, D., Silginer, M. et al. ( 2016 ) Control of glioma cell migration and invasiveness by GDF-15. Oncotarget 7: 7732-46.

47. Liu, M.F., Jin, T., Shen, J.H., Shen, Z.Y., Zheng, Z.C. et al. (2011)NGAL and NGALR are frequently overexpressed in human gliomas and are associated with clinical prognosis. J Neurooncol 104: $119-27$

48. Su, J., Guo, B., Zhang, T., Wang, K., Li, X. et al. (2015) Stanniocalcin-1, a new biomarker of glioma progression, is associated with prognosis of patients. Tumour Biol 36: 6333-9.

49. Manjula, S., Aroor, A.R., Raja, A., Rao, S.N., Rao, A. (1992) Elevation of serum ceruloplasmin levels in brain tumours. Acta Neurol Scand 86: $156-8$. 
50. Sytinskii, I.A., Chaika, T.V., Blagova, O.E., Konovalova, N.N., Mikhailova, G.N. ( 1979) [Aminotransferase and dehydrogenase activity in human brain tumours]. Ukr Biokhim Zh (1978) 51: 111-6.

51. Lin, J.P., Pan, B.C., Li, B., Li, Y., Tian, X.Y. et al. (2014) DJ-1 is activated in medulloblastoma and is associated with cell proliferation and differentiation. World J Surg Oncol 12: 373.

52. Martelli, C., lavarone, F., D'Angelo, L., Arba, M., Vincenzoni, F. et al. (2015) Integrated proteomic platforms for the comparative characterization of medulloblastoma and pilocytic astrocytoma pediatric brain tumors: a preliminary study. Mol Biosyst 11: 1668-83.

53. Ohtaki, S., Wanibuchi, M., Kataoka-Sasaki, Y., Sasaki, M., Oka, S. et al. (2017) ACTC1 as an invasion and prognosis marker in glioma. J Neurosurg 126: 467-475.

54. Yan, H., Yang, K., Xiao, H., Zou, Y.J., Zhang, W.B. et al. (2012) Over-expression of cofilin-1 and phosphoglycerate kinase 1 in astrocytomas involved in pathogenesis of radioresistance. CNS Neurosci Ther 18: $729-36$.

55. Wu, H., Yang, L., Liao, D., Chen, Y., Wang, W. et al. (2013) Podocalyxin regulates astrocytoma cell invasion and survival against temozolomide. Exp Ther Med 5: 1025-1029.

56. El Hindy, N., Rump, K., Lambertz, N., Zhu, Y., Frey, U.H. et al. (2013) The functional Aquaporin $1-783 \mathrm{G} / \mathrm{C}$-polymorphism is associated with survival in patients with glioblastoma multiforme. J Surg Oncol 108: 492-8.

57. He, Q., Shi, X., Zhang, L., Yi, C., Zhang, X. et al. (2016) De Novo Glutamine Synthesis: Importance for the Proliferation of Glioma Cells and Potentials for Its Detection With 13N-Ammonia. Mol Imaging 15:

58. Reynes, G., Vila, V., Martin, M., Parada, A., Fleitas, T. et al. (2011) Circulating markers of angiogenesis, inflammation, and coagulation in patients with glioblastoma. J Neurooncol 102: $35-41$.

59. Nygren, C., von Holst, H., Mansson, J.E., Fredman, P. (1997) Increased activity of lysosomal glycohydrolases in glioma tissue and surrounding areas from human brain. Acta Neurochir (Wien) 139: 146-50.

60. Han, S., Lv, X., Wang, Y., Gong, H., Zhang, C. et al. (2015) Effect and mechanism of peroxisome proliferator-activated receptor-gamma on the drug resistance of the U-87 MG/CDDP human malignant glioma cell line. Mol Med Rep 12: 2239-46.

61. Kandil, S., Brennan, L., McBean, G.J. (2010) Glutathione depletion causes a JNK and p38MAPK-mediated increase in expression of cystathionine-gamma-lyase and upregulation of the transsulfuration pathway in C6 glioma cells. Neurochem Int 56: 611-9.

62. Bensalma, S., Chadeneau, C., Legigan, T., Renoux, B., Gaillard, A. et al. (2015) Evaluation of cytotoxic properties of a cyclopamine glucuronide prodrug in rat glioblastoma cells and tumors. J Mol Neurosci 55: 51-61.

63. Monod, L., Hamou, M.F., Ronco, P., Verroust, P., de Tribolet, N. (1992) Expression of CALLa/NEP on gliomas: a possible marker of malignancy. Acta Neurochir (Wien) 114: 3-7. 


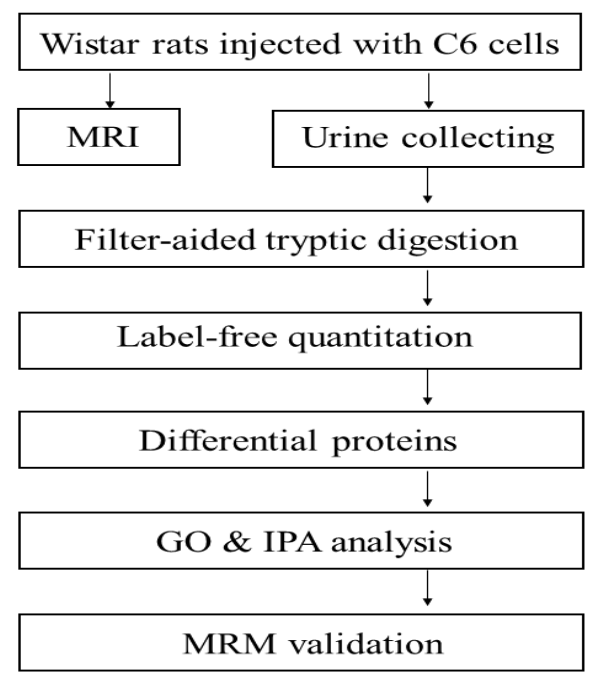

Fig 1. Workflow of protein identification in the GBM rats model. Urine samples were collected from the control and GBM groups. The proteins were analyzed by label-free proteomic analysis. The differential proteins were analyzed by GO and IPA. MRM was used to validate the key differentially expressed proteins.
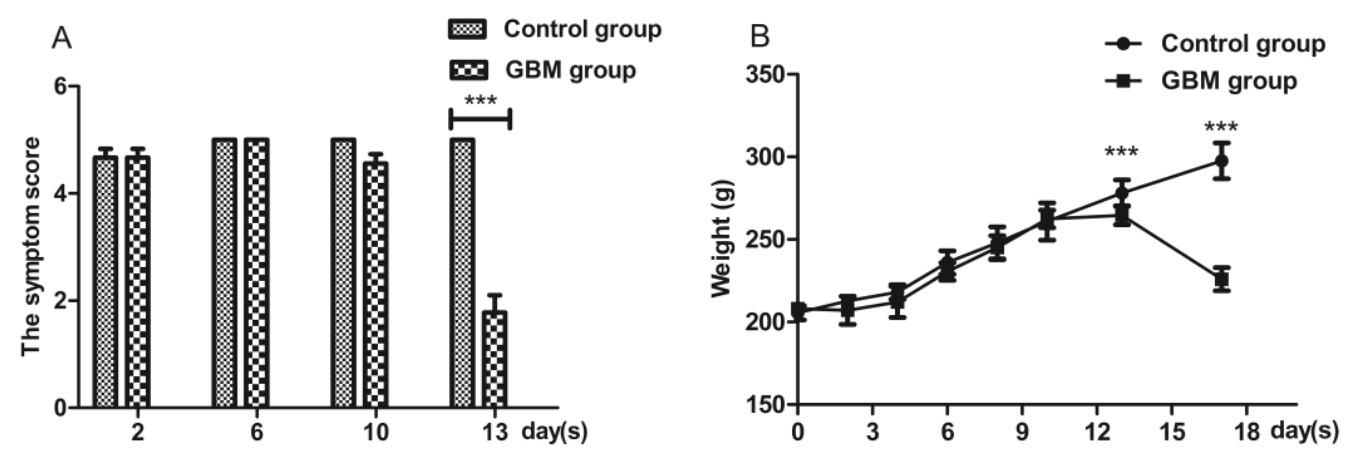

Fig 2. Clinical parameters of rats in control and GBM rats. (a) The symptom scores of GBM rats were significantly decreased on 13 th day after tumor cells injection $(\mathrm{P}=0.001)$. (b) The weight of GBM rats were significantly decreased on 17 th day $(\mathrm{P}<0.001)$.
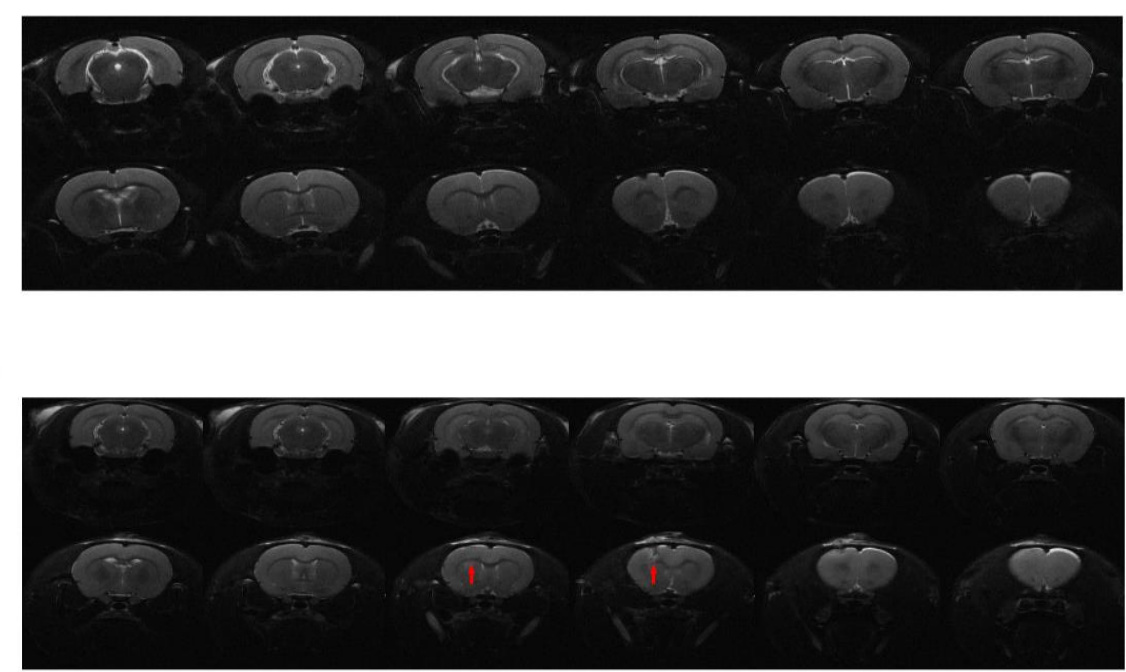


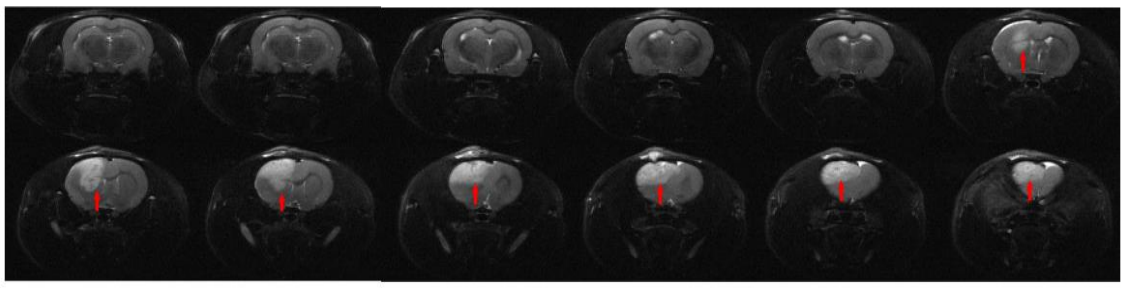

Fig 3. MRI results of the brain tissues after an injection with tumor cells (A) MRI results of the brain tissues on the 6th day. (B) MRI results of the brain tissues on the 10th day. The red arrow indicates the cancer tissues. (C) MRI results of the brain tissues on the 13th day. Red arrows indicate the cancer tissues and the shifted midline.
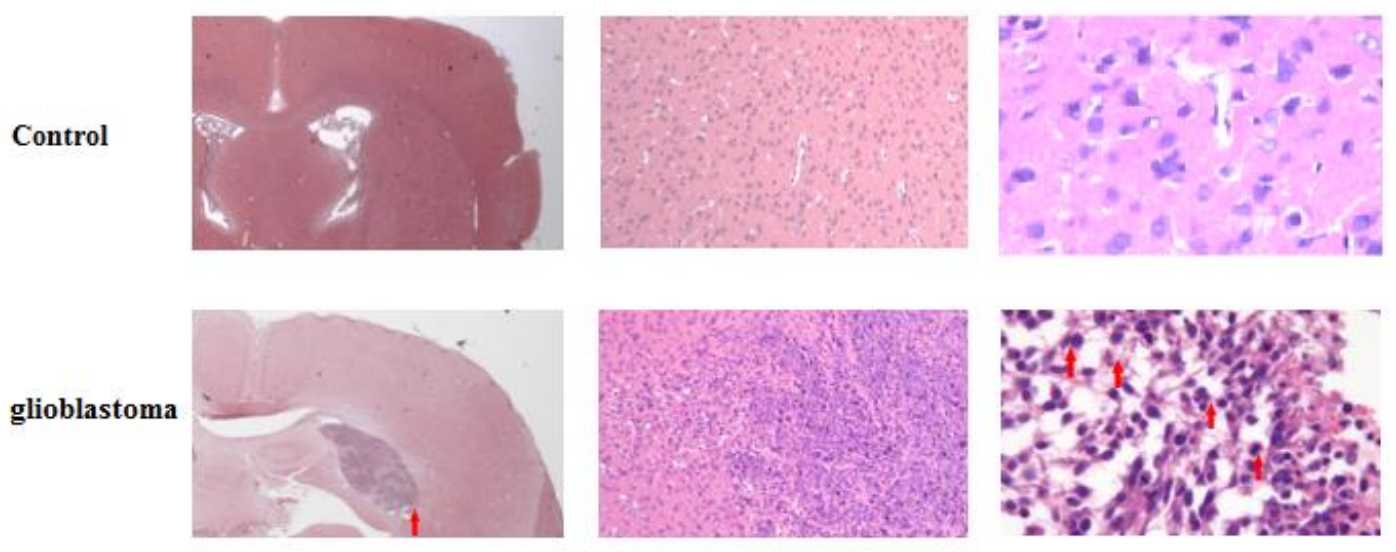

Fig 4. H\&E staining of brain tissues on the 13th day after an injection with rat glioma C6 cells. (A) H\&E staining (7.5x). The red arrow indicates cancer tissues. (B) H\&E staining (100x). (C) H\&E staining $(400 \times)$. The red arrow indicates tumor mitotic figure.
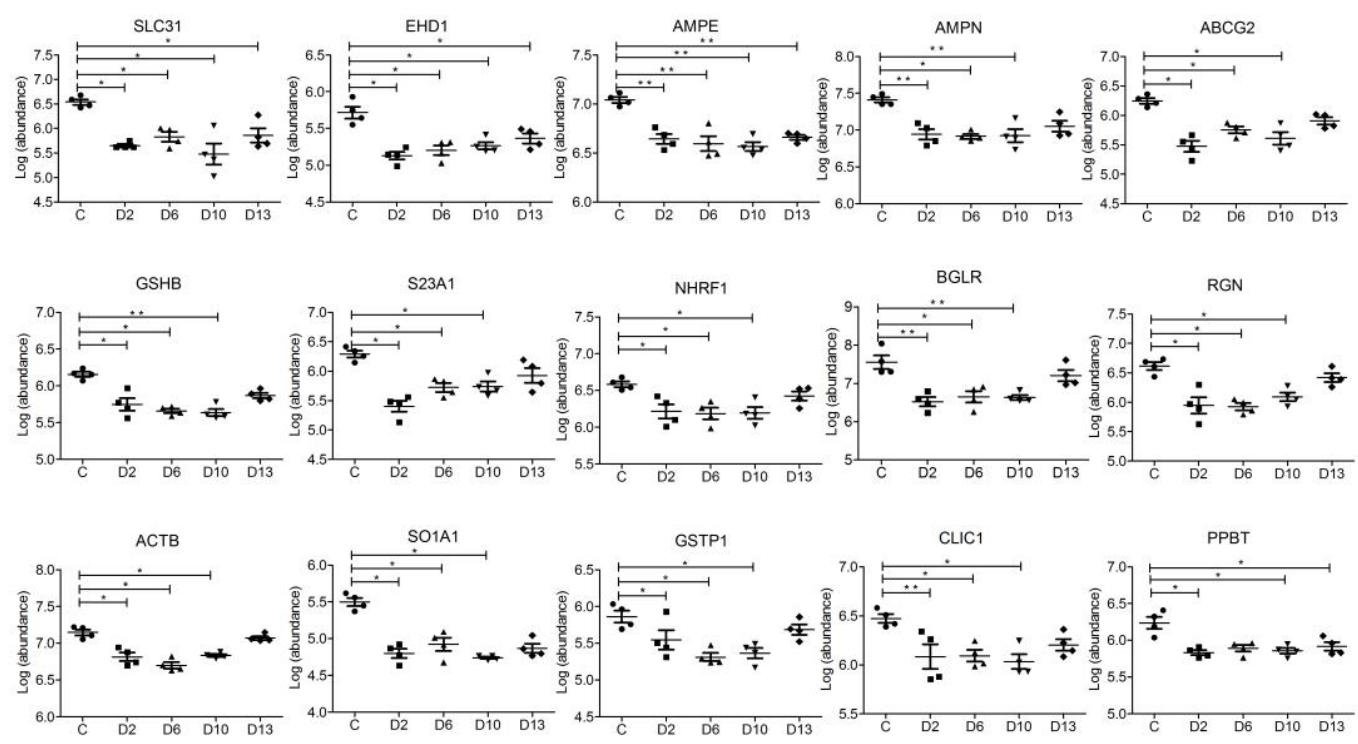

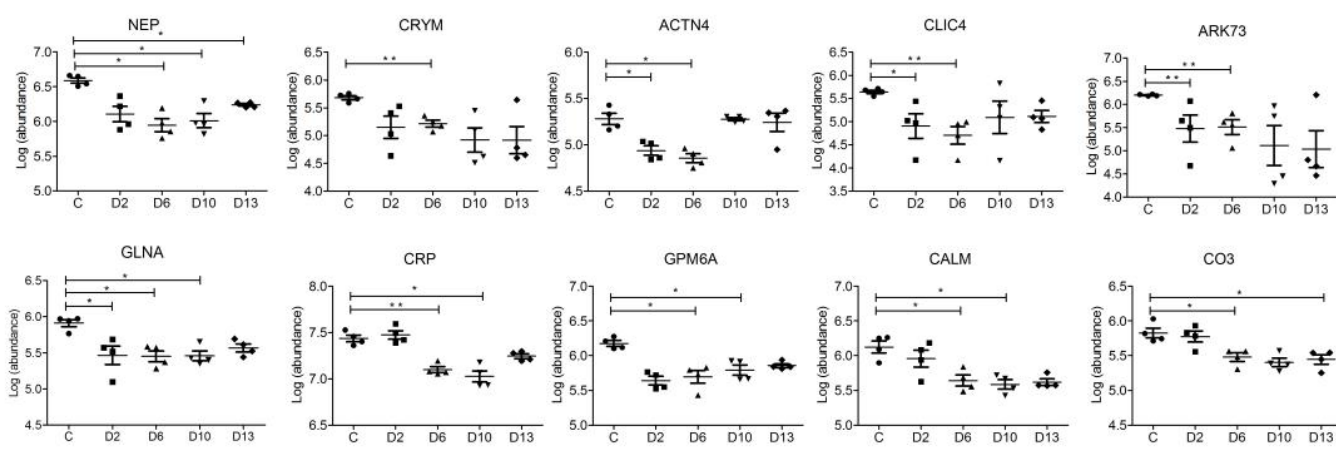

GPM6A

CALM
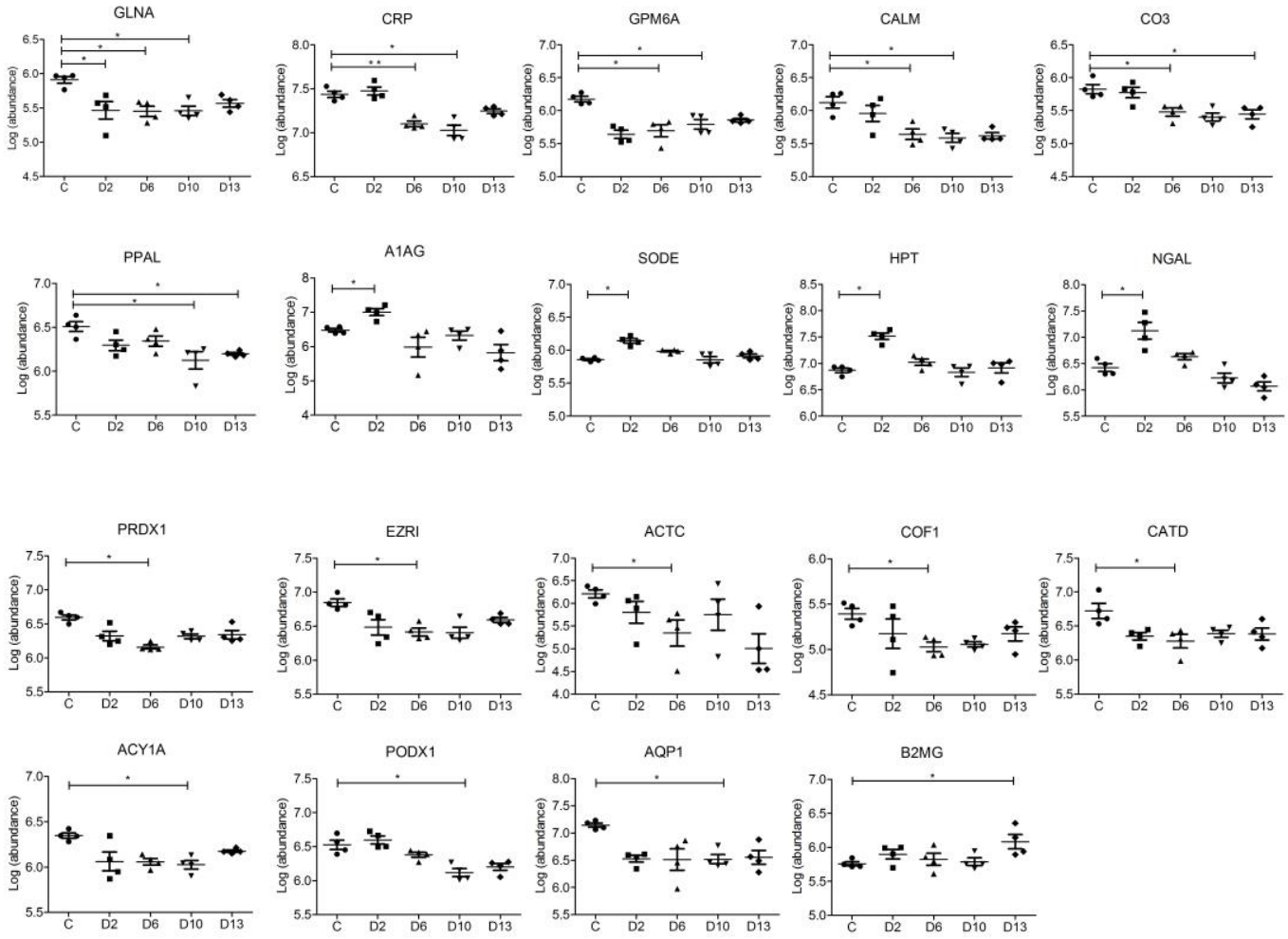

Fig 5. MRM results of candidate urine biomarkers of GBM. Thirty-four proteins shared a decreasing trend in relative abundance, five proteins shared an increasing trend. The x-axis represents different groups; the y-axis refers to the log transformation of the normalized abundance identified by skyline software. 

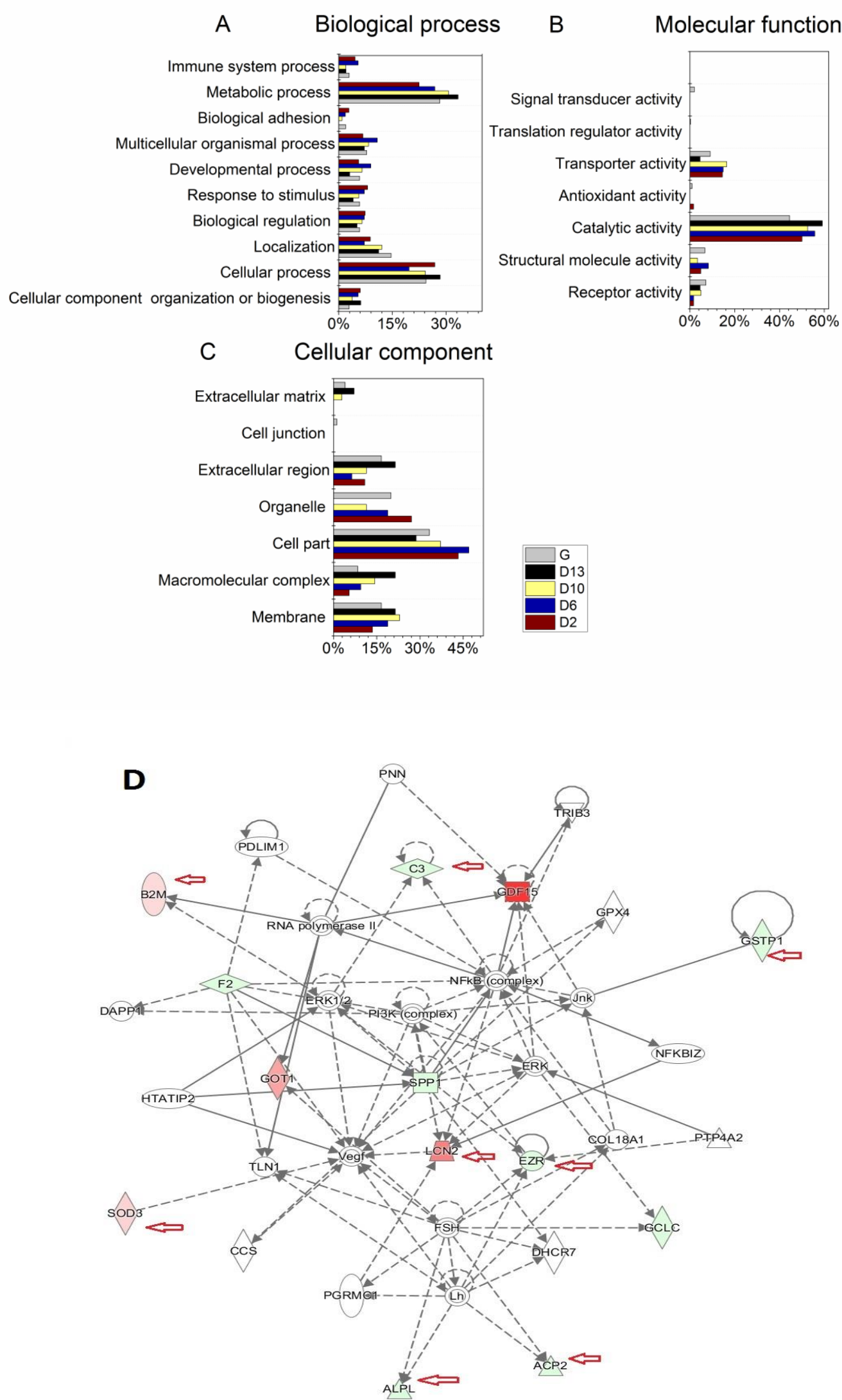

Fig 6. Panther and IPA network analysis of differential proteins. (A) The molecular function analysis between the control and GBM groups; (B) The biological process analysis between the 
control and GBM groups. (C) The cellular component analysis between the control and GBM groups.(D) Death and Survival networks from IPA analysis. Proteins in red were up-regulated in GBM compared with control rats, and proteins in green were down-regulated in GBM. Proteins pointed by the red arrow were validated using MRM.

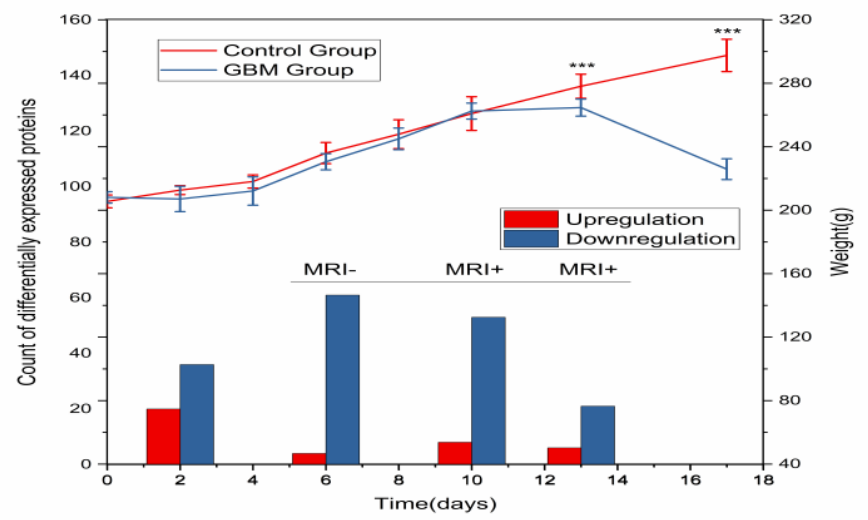

Fig 7. A panel or collection of differential urinary proteins can provide clues for the early diagnose of GBM. Clinical manifestation may provide clues on the 13th day after tumor cell implantation, while the enhancement lesion appeared in MRI on the 10th day. However, the urinary differential proteins of three rats can provide valuable clues by the 2 nd and 6 th day.

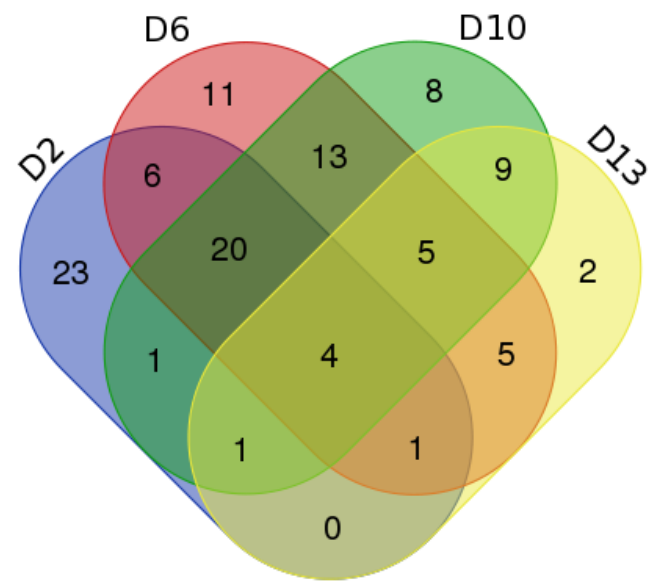

Fig S1. The differential proteins identified in GBM rats. Compared with control group, four proteins were identified in all four GBM groups; twenty-seven proteins were identified in three GBM groups; thirty-four proteins were identified in two GBM groups.

Table 1. Number of up-regulated and down-regulated differential proteins in different GBM groups.

\begin{tabular}{c|ccc}
\hline Group & Upregulation & Downregulation & Total \\
\hline D2 & 20 & 36 & 778 \\
\hline Percentage & 2.57 & 4.62 & 100 \\
D6 & 4 & 61 & 778 \\
Percentage & 0.51 & 7.84 & 100 \\
D10 & 8 & 53 & 778 \\
\hline
\end{tabular}




\begin{tabular}{c|ccc}
\hline Percentage & 1.02 & 6.81 & 100 \\
D13 & 6 & 21 & 778 \\
\hline Percentage & 0.77 & 2.69 & 100 \\
Total (differential proteins) & 31 & 78 & 109 \\
\hline
\end{tabular}

Table 2. Details of urinary differential proteins identified on the 2nd and 6th day groups.

\begin{tabular}{|c|c|c|c|c|c|c|c|c|c|c|}
\hline \multirow{2}{*}{$\begin{array}{c}\text { Uniprot } \\
\text { ID }\end{array}$} & \multirow{2}{*}{ Protein name } & \multirow{2}{*}{ Accession } & \multirow{2}{*}{ Trend } & \multicolumn{4}{|c|}{ Fold Change } & \multirow{2}{*}{$\begin{array}{l}\text { Associate } \\
\text { with GBM }\end{array}$} & \multirow{2}{*}{ MRM } & \multirow{2}{*}{$\begin{array}{l}\text { Candidate } \\
\text { biomarker }\end{array}$} \\
\hline & & & & D2 & D6 & D10 & D13 & & & \\
\hline P07911 & Uromodulin & UROM & $\uparrow$ & 6.37 & - & - & - & No & No & Yes \\
\hline Q99988 & $\begin{array}{c}\text { Growth/differentiation } \\
\text { factor } 15\end{array}$ & GDF15 & $\uparrow$ & 12.1 & - & - & - & $\begin{array}{c}\text { Blood, CSF } \\
{[46]}\end{array}$ & No & No \\
\hline P80188 & $\begin{array}{c}\text { Neutrophil } \\
\text { gelatinase-associated } \\
\text { lipocalin }\end{array}$ & $\mathrm{LNC} 2$ & $\uparrow$ & 7.64 & - & - & - & Tissue [47] & Yes & Yes \\
\hline P52823 & Stanniocalcin-1 & STC1 & $\uparrow$ & 3.41 & - & - & - & Tissue [48] & No & No \\
\hline P08294 & $\begin{array}{l}\text { Extracellular superoxide } \\
\text { dismutase }[\mathrm{Cu}-\mathrm{Zn}]\end{array}$ & SODE & $\uparrow$ & 2.60 & - & - & - & No & Yes & Yes \\
\hline P00739 & Haptoglobin & HPT & $\uparrow$ & 4.58 & - & - & - & Blood [32] & Yes & No \\
\hline $\mathrm{P} 02763$ & $\begin{array}{l}\text { Alpha-1-acid } \\
\text { glycoprotein }\end{array}$ & $\mathrm{A} 1 \mathrm{AG}$ & $\uparrow$ & 7.33 & - & - & - & Blood [34] & Yes & Yes \\
\hline P08571 & Ceruloplasmin & CERU & $\uparrow$ & 2.21 & - & - & - & Blood [49] & No & Yes \\
\hline P07108 & $\begin{array}{l}\text { Acyl-CoA-binding } \\
\text { protein }\end{array}$ & ACBP & $\uparrow$ & 3.43 & - & - & - & No & No & Yes \\
\hline Q13103 & $\begin{array}{c}\text { Secreted } \\
\text { phosphoprotein } 24\end{array}$ & SPP24 & $\uparrow$ & 2.80 & - & - & - & No & No & No \\
\hline Q02818 & Nucleobindin-1 & NUCB1 & $\uparrow$ & 2.07 & - & - & - & No & No & No \\
\hline P24855 & $\begin{array}{l}\text { Deoxyribonuclease-1 } \\
\text { Inter-alpha-trypsin }\end{array}$ & DNAS1 & $\uparrow$ & 2.27 & - & - & - & No & No & No \\
\hline Q06033 & $\begin{array}{c}\text { inhibitor heavy chain } \\
\text { H3 }\end{array}$ & ITIH3 & $\downarrow$ & 0.37 & - & - & - & No & No & No \\
\hline P17174 & $\begin{array}{c}\text { Aspartate } \\
\text { aminotransferase }\end{array}$ & AATC & $\uparrow$ & 5.43 & - & - & - & Tissue [50] & No & No \\
\hline Q99497 & Protein deglycase DJ-1 & PARK7 & $\uparrow$ & 3.70 & - & - & - & $\begin{array}{c}\text { Tumor cells } \\
\text { [51] }\end{array}$ & No & No \\
\hline P68871 & $\begin{array}{c}\text { Hemoglobin subunit } \\
\text { beta- } 2\end{array}$ & HBB2 & $\uparrow$ & 8.35 & - & - & - & No & No & Yes \\
\hline P01011 & $\begin{array}{l}\text { Serine protease inhibitor } \\
\qquad \text { A3M (Fragment) }\end{array}$ & SPA3M & $\uparrow$ & 2.75 & - & - & - & No & No & Yes \\
\hline P68871 & $\begin{array}{l}\text { Hemoglobin subunit } \\
\text { beta-1 }\end{array}$ & HBB1 & $\uparrow$ & 13.8 & - & - & - & No & No & Yes \\
\hline P26992 & $\begin{array}{l}\text { Ciliary neurotrophic } \\
\text { factor receptor subunit } \\
\text { alpha }\end{array}$ & CNTFR & $\uparrow$ & 2.39 & - & - & - & Tissue [31] & No & No \\
\hline Q99519 & Sialidase-1 & NEUR1 & $\downarrow$ & 0.46 & - & - & - & No & No & No \\
\hline
\end{tabular}




\begin{tabular}{|c|c|c|c|c|c|c|c|c|c|c|}
\hline O95968 & $\begin{array}{c}\text { Prostatic steroid-binding } \\
\text { protein } \mathrm{C} 1\end{array}$ & $\mathrm{PSC} 1$ & $\uparrow$ & 7.75 & - & - & - & No & No & No \\
\hline P02533 & $\begin{array}{l}\text { Keratin, type I } \\
\text { cytoskeletal } 14\end{array}$ & $\mathrm{~K} 1 \mathrm{C} 14$ & $\downarrow$ & 0.25 & - & - & - & No & No & No \\
\hline P55259 & $\begin{array}{c}\text { Pancreatic secretory } \\
\text { granule membrane } \\
\text { major glycoprotein GP2 }\end{array}$ & GP2 & $\uparrow$ & 4.98 & - & - & - & No & No & No \\
\hline Q06830 & Peroxiredoxin-1 & PRDX1 & $\downarrow$ & - & 0.34 & - & - & Tissue [52] & Yes & No \\
\hline P52758 & Ribonuclease UK114 & UK114 & $\downarrow$ & - & 0.49 & - & - & No & No & No \\
\hline P02768 & Serum albumin & ALBU & $\downarrow$ & - & 0.48 & - & - & No & No & Yes \\
\hline P68032 & $\begin{array}{l}\text { Actin, alpha cardiac } \\
\text { muscle } 1\end{array}$ & ACTC & $\downarrow$ & - & 0.46 & - & - & Tissue [53] & Yes & No \\
\hline P07339 & Cathepsin D & CATD & $\downarrow$ & - & 0.47 & - & - & $\begin{array}{c}\text { Tumor cells } \\
\text { [35] }\end{array}$ & Yes & No \\
\hline P15311 & Ezrin & EZRI & $\downarrow$ & - & 0.46 & - & - & Tissue [27] & Yes & No \\
\hline P68104 & $\begin{array}{l}\text { Elongation factor } \\
\text { 1-alpha } 1\end{array}$ & EF1A1 & $\downarrow$ & - & 0.34 & - & - & No & No & No \\
\hline P0CG47 & Polyubiquitin-B & UBB & $\downarrow$ & - & 0.43 & - & - & No & No & No \\
\hline Q96BW5 & $\begin{array}{c}\text { Phosphotriesterase-relat } \\
\text { ed protein }\end{array}$ & PTER & $\downarrow$ & - & 0.42 & - & - & No & No & No \\
\hline P23528 & Cofilin-1 & COF1 & $\downarrow$ & - & 0.40 & - & - & Tissue [54] & Yes & No \\
\hline P01834 & $\begin{array}{c}\text { Ig kappa chain } \mathrm{C} \text { region, } \\
\text { A allele }\end{array}$ & KACA & $\uparrow$ & - & 3.13 & - & - & No & No & Yes \\
\hline O00592 & Podocalyxin & PODXL & $\downarrow$ & & & 0.47 & & Yes [55] & Yes & Yes \\
\hline P21281 & $\begin{array}{l}\text { V-type proton ATPase } \\
\text { subunit B, brain isoform }\end{array}$ & VATB2 & $\downarrow$ & & & 0.45 & & No & No & No \\
\hline P00995 & $\begin{array}{l}\text { Serine protease inhibitor } \\
\text { Kazal-type 1-like }\end{array}$ & ISK1L & $\downarrow$ & & & 0.32 & & No & No & Yes \\
\hline P49189 & $\begin{array}{l}\text { 4-trimethylaminobutyral } \\
\text { dehyde dehydrogenase }\end{array}$ & AL9A1 & $\downarrow$ & & & 0.31 & & No & No & No \\
\hline P29972 & Aquaporin-1 & AQP1 & $\downarrow$ & & & 0.49 & & Yes [56] & Yes & Yes \\
\hline P06870 & $\begin{array}{l}\text { Prostatic glandular } \\
\text { kallikrein-6 }\end{array}$ & KLK6 & $\uparrow$ & & & 2.65 & & No & No & No \\
\hline P08118 & $\begin{array}{l}\text { Beta-microseminoprotei } \\
\mathrm{n}\end{array}$ & MSMB & $\uparrow$ & & & 5.87 & & No & No & Yes \\
\hline P06870 & $\begin{array}{c}\text { Submandibular } \\
\text { glandular kallikrein-9 }\end{array}$ & KLK9 & $\uparrow$ & & & 3.47 & & No & No & No \\
\hline P61769 & Beta-2-microglobulin & B2MG & $\uparrow$ & & & & 2.15 & No & Yes & Yes \\
\hline P07195 & $\begin{array}{l}\text { L-lactate dehydrogenase } \\
\text { B chain }\end{array}$ & LDHB & $\downarrow$ & & & & 0.34 & No & No & Yes \\
\hline Q9HBJ8 & Collectrin & TMM27 & $\downarrow$ & 0.34 & 0.26 & - & - & No & No & No \\
\hline P15104 & Glutamine synthetase & GLNA & $\downarrow$ & 0.47 & 0.42 & - & - & $\begin{array}{c}\text { Tumor cells } \\
\text { [57] }\end{array}$ & Yes & No \\
\hline Q92859 & Neogenin (Fragment) & NEO1 & $\downarrow$ & 0.35 & 0.27 & - & - & No & No & No \\
\hline
\end{tabular}




\begin{tabular}{|c|c|c|c|c|c|c|c|c|c|c|}
\hline Q14894 & $\begin{array}{c}\text { Ketimine reductase } \\
\text { mu-crystallin }\end{array}$ & CRYM & $\downarrow$ & 0.44 & 0.46 & - & - & No & Yes & No \\
\hline O95154 & $\begin{array}{l}\text { Aflatoxin B1 aldehyde } \\
\text { reductase member } 3\end{array}$ & ARK73 & $\downarrow$ & 0.25 & 0.27 & - & - & No & Yes & No \\
\hline O43707 & Alpha-actinin-4 & ACTN4 & $\downarrow$ & 0.04 & 0.15 & - & - & Tissue [21] & Yes & No \\
\hline O14556 & $\begin{array}{l}\text { Glyceraldehyde-3-phosp } \\
\text { hate dehydrogenase }\end{array}$ & G3PT & $\downarrow$ & 0.07 & - & 0.17 & - & No & No & No \\
\hline Q96HD9 & $\begin{array}{l}\text { N-acyl-aromatic-L-amin } \\
\text { o acid amidohydrolase }\end{array}$ & ACY3 & $\downarrow$ & - & 0.26 & 0.38 & - & No & No & No \\
\hline Q96KP4 & $\begin{array}{c}\text { Cytosolic non-specific } \\
\text { dipeptidase }\end{array}$ & CNDP2 & $\downarrow$ & - & 0.42 & 0.43 & - & No & No & No \\
\hline P02741 & C-reactive protein & CRP & $\downarrow$ & - & 0.39 & 0.42 & - & Blood [24] & Yes & Yes \\
\hline P50053 & Ketohexokinase & KHK & $\downarrow$ & - & 0.27 & 0.38 & - & No & No & No \\
\hline Q9H0W9 & $\begin{array}{c}\text { Ester hydrolase } \\
\text { C11orf54 homolog }\end{array}$ & CK054 & $\downarrow$ & - & 0.41 & 0.48 & - & No & No & No \\
\hline P09467 & $\begin{array}{c}\text { Fructose-1,6-bisphospha } \\
\text { tase } 1\end{array}$ & $\begin{array}{c}\mathrm{F} 16 \mathrm{P} 1 ; \mathrm{F} 1 \\
\text { 6P2 }\end{array}$ & $\downarrow$ & - & 0.38 & 0.41 & - & No & No & No \\
\hline Q2TAA2 & $\begin{array}{c}\text { Isoamyl } \\
\text { acetate-hydrolyzing } \\
\text { esterase } 1 \text { homolog }\end{array}$ & IAH1 & $\downarrow$ & - & 0.35 & 0.42 & - & No & No & No \\
\hline Q86X76 & Nitrilase homolog 1 & NIT1 & $\downarrow$ & - & 0.26 & 0.40 & - & No & No & No \\
\hline Q16820 & Meprin A subunit beta & MEP1B & $\downarrow$ & - & 0.38 & 0.46 & - & No & No & No \\
\hline P62158 & Calmodulin & CALM & $\downarrow$ & - & 0.42 & 0.49 & - & No & Yes & No \\
\hline P51674 & $\begin{array}{l}\text { Neuronal membrane } \\
\text { glycoprotein M6-a }\end{array}$ & GPM6A & $\downarrow$ & - & 0.27 & 0.40 & - & No & Yes & No \\
\hline P60174 & $\begin{array}{c}\text { Triosephosphate } \\
\text { isomerase }\end{array}$ & TPIS & $\downarrow$ & - & 0.43 & 0.47 & - & Tissue [52] & No & Yes \\
\hline Q96DA0 & $\begin{array}{c}\text { Prostatic } \\
\text { spermine-binding } \\
\text { protein }\end{array}$ & SPBP & $\uparrow$ & - & 2.78 & 4.21 & - & No & No & No \\
\hline P01859 & $\begin{array}{c}\text { Ig gamma-1 chain } \mathrm{C} \\
\text { region }\end{array}$ & IGHG1 & $\uparrow$ & & & 6.42 & 9.42 & No & No & Yes \\
\hline P00734 & Prothrombin & THRB & $\downarrow$ & & & 0.45 & 0.43 & Yes [58] & No & No \\
\hline P16112 & Aggrecan core protein & PGCA & $\downarrow$ & & & 0.45 & 0.46 & No & No & No \\
\hline P11117 & $\begin{array}{c}\text { Lysosomal acid } \\
\text { phosphatase }\end{array}$ & PPAL & $\downarrow$ & & & 0.44 & 0.48 & Yes [59] & Yes & No \\
\hline P20472 & Parvalbumin alpha & PRVA & $\uparrow$ & & & 4.11 & 3.86 & No & No & No \\
\hline P36896 & $\begin{array}{l}\text { Activin receptor } \\
\text { type-1B }\end{array}$ & ACV1B & $\downarrow$ & & & 0.48 & 0.44 & No & No & No \\
\hline P00966 & $\begin{array}{l}\text { Argininosuccinate } \\
\text { synthase }\end{array}$ & ASSY & $\downarrow$ & & & 0.45 & 0.41 & No & No & No \\
\hline P10451 & Osteopontin & SPP1 & $\downarrow$ & & & 0.25 & 0.29 & Yes [28] & No & Yes \\
\hline P01859 & $\begin{array}{c}\text { Ig gamma-2A chain } \mathrm{C} \\
\text { region }\end{array}$ & IGG2A & $\uparrow$ & & & 2.78 & 0.45 & No & No & No \\
\hline
\end{tabular}




\begin{tabular}{|c|c|c|c|c|c|c|c|c|c|}
\hline P01024 & Complement $\mathrm{C} 3$ & $\mathrm{CO} 3$ & $\downarrow$ & - & 0.40 & - & 0.45 & Tissue [25] & Yes \\
\hline O00764 & Pyridoxal kinase & PDXK & $\downarrow$ & - & 0.19 & - & 0.21 & No & No \\
\hline P01834 & $\begin{array}{c}\text { Ig kappa chain } \mathrm{C} \text { region, } \\
\text { B allele }\end{array}$ & KACB & $\uparrow$ & - & 2.01 & - & 2.22 & No & No \\
\hline Q06495 & $\begin{array}{l}\text { Sodium-dependent } \\
\text { phosphate transport } \\
\text { protein } 2 \mathrm{~A}\end{array}$ & NPT2A & $\downarrow$ & - & 0.10 & - & 0.20 & No & No \\
\hline P68371 & Tubulin beta-4B chain & ТВB4B & $\downarrow$ & - & 0.36 & - & 0.34 & No & No \\
\hline P15144 & Aminopeptidase $\mathrm{N}$ & AMPN & $\downarrow$ & 0.33 & 0.30 & 0.46 & - & Tissue [38] & Yes \\
\hline P48637 & Glutathione synthetase & GSHB & $\downarrow$ & 0.44 & 0.20 & 0.31 & - & $\begin{array}{c}\text { Tumor cells } \\
\text { [60] }\end{array}$ & Yes \\
\hline Q15493 & Regucalcin & RGN & $\downarrow$ & 0.28 & 0.18 & 0.33 & - & No & Yes \\
\hline P19440 & $\begin{array}{c}\text { Gamma-glutamyltransp } \\
\text { eptidase } 1\end{array}$ & GGT1 & $\downarrow$ & 0.38 & 0.31 & 0.45 & - & No & No \\
\hline P46721 & $\begin{array}{l}\text { Solute carrier organic } \\
\text { anion transporter family } \\
\text { member } 1 \mathrm{~A} 1\end{array}$ & SO1A1 & $\downarrow$ & 0.07 & 0.08 & 0.23 & - & No & Yes \\
\hline P48507 & $\begin{array}{c}\text { Glutamate--cysteine } \\
\text { ligase regulatory subunit }\end{array}$ & GSHO & $\downarrow$ & 0.32 & 0.28 & 0.40 & - & No & No \\
\hline P32929 & $\begin{array}{l}\text { Cystathionine } \\
\text { gamma-lyase }\end{array}$ & CGL & $\downarrow$ & 0.27 & 0.25 & 0.41 & - & $\begin{array}{c}\text { Tumor cells } \\
\text { [61] }\end{array}$ & No \\
\hline Q08257 & Quinone oxidoreductase & QOR & $\downarrow$ & 0.37 & 0.27 & 0.34 & - & No & No \\
\hline P60709 & Actin, cytoplasmic 1 & ACTB & $\downarrow$ & 0.49 & 0.32 & 0.44 & - & No & Yes \\
\hline Q9Y696 & $\begin{array}{l}\text { Chloride intracellular } \\
\text { channel protein } 4\end{array}$ & CLIC4 & $\downarrow$ & 0.33 & 0.25 & 0.41 & - & No & Yes \\
\hline Q96N87 & $\begin{array}{l}\text { Sodium-dependent } \\
\text { neutral amino acid } \\
\text { transporter B (0) AT3 }\end{array}$ & S6A18 & $\downarrow$ & 0.08 & 0.09 & 0.16 & - & No & No \\
\hline P09211 & $\begin{array}{c}\text { Glutathione } \\
\text { S-transferase P }\end{array}$ & GSTP1 & $\downarrow$ & 0.37 & 0.22 & 0.28 & - & Tissue [37] & Yes \\
\hline P48506 & $\begin{array}{l}\text { Glutamate--cysteine } \\
\text { ligase catalytic subunit }\end{array}$ & GSH1 & $\downarrow$ & 0.48 & 0.31 & 0.41 & - & Yes & No \\
\hline O00338 & Sulfotransferase $1 \mathrm{C} 2 \mathrm{~A}$ & $\mathrm{~S} 1 \mathrm{C} 2 \mathrm{~A}$ & $\downarrow$ & 0.36 & 0.28 & 0.39 & - & No & No \\
\hline Q9UHI7 & $\begin{array}{c}\text { Solute carrier family } 23 \\
\text { member1 }\end{array}$ & S23A1 & $\downarrow$ & 0.25 & 0.18 & 0.20 & - & No & Yes \\
\hline P08236 & Beta-glucuronidase & BGLR & $\downarrow$ & 0.11 & 0.08 & 0.13 & - & Tissue [62] & Yes \\
\hline $\mathrm{P} 23526$ & $\begin{array}{c}\text { Adenosylhomocysteinas } \\
\text { e }\end{array}$ & SAHH & $\downarrow$ & 0.25 & 0.23 & 0.33 & - & No & No \\
\hline O00299 & $\begin{array}{l}\text { Chloride intracellular } \\
\text { channel protein } 1\end{array}$ & CLIC1 & $\downarrow$ & 0.45 & 0.34 & 0.49 & - & Tissue [36] & Yes \\
\hline O14745 & $\begin{array}{c}\mathrm{Na}(+) / \mathrm{H}(+) \text { exchange } \\
\text { regulatory cofactor }\end{array}$ & NHRF1 & $\downarrow$ & 0.38 & 0.28 & 0.37 & - & No & Yes \\
\hline Q9UNQ0 & ATP-binding cassette & $\mathrm{ABCG} 2$ & $\downarrow$ & 0.32 & 0.27 & 0.41 & - & No & Yes \\
\hline
\end{tabular}


sub-family G member 2

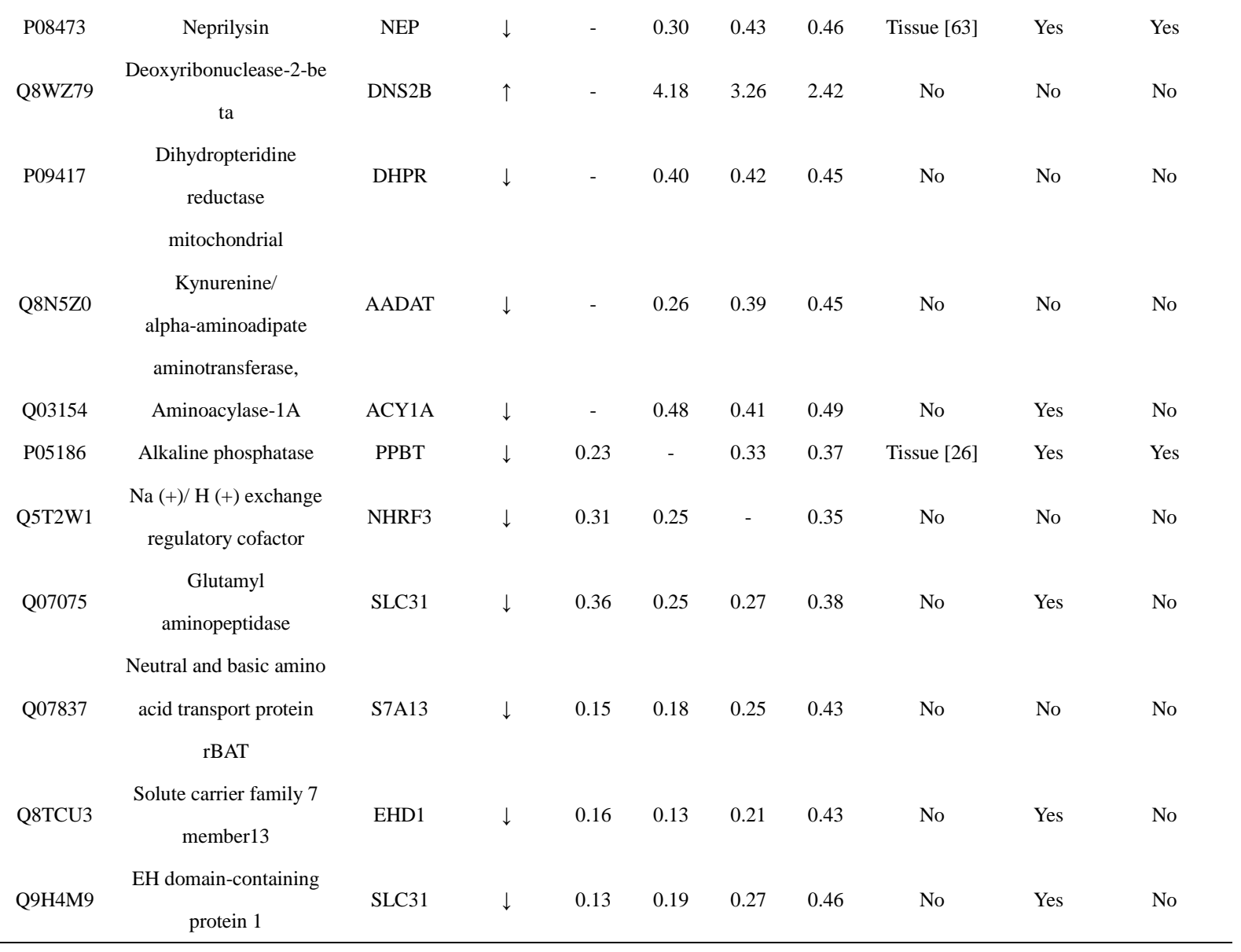

